\title{
EXCURSION TO THE TATTINGSTONE CRAG DISTRICT OF SUFFOLK.
}

\author{
Saturday, 6th June, 1896. \\ Directors: The President and E. P. Ridley, F.G.S. \\ Excursion Secretary: A. C. Young. \\ (Report by The Directors.)
}

ARriving at Bentley Station the party was joined by members of the Ipswich Scientific Society, and collected first from two Red Crag sections close to the station, both of which had been specially opened for the occasion. Leaving these, a walk of about a mile brought the party to other Red Crag pits, near Tattingstone "White Horse." In all these sections specimens were very abundant, but generally much broken. The following were amongst the finds of the various members of the party:

Capulus

Cerithium

Cyprea Europea

Emarginula

Nassa reticosa

Natica

Pleurotoma

Purpura lapillus

tetragona

Trochus subexcavatus

Trophon antiquus

Turritella incrassata

Voluta Lamberti

Artemis lincta

Astarte Basteroti

" sulcata
Cardita senilis

Cardium sp.

Cyprina Islandica

Diplodonta astartea

Mactra sp.

Modiola

Mya arenaria

Ostrea

Pecten maximus

" opercularis

Pholas

Tellina

Venus casina

Crab claws

Balanophyllia caliculus

Sphenotrochus

A move was then made to Tattingstone Hall, and after lunch the junction of the Red Crag and the Coralline Crag was examined at an opening in the farm yard. The section here formerly exhibited the unconformity between the two formations, as is shown in the figure (p. 4Io), and has been described by Lyell and Prestwich.

The Coralline Crag (Bed 8 in the figure) has been so greatly eroded that only a reef has been left, and the Red Crag (Beds 2 to 7 ) rests on the eroded surface and is banked against a cliff of the older rock. The section figured above is now obscured, but the Coralline Crag and the junction are still well exposed and were carefully examined. Here the "White Crag" consists almost entirely of fine comminuted white shells mixed up with

November, i 896.$]$ 
small pieces of polyzoa. Mr. Kennard found a Solen in its natural position boring into the upper part of the Coralline Crag. In the shelly part of the Red Crag Pcctunculus was abundant, and from the base of this bed, just above the Coralline Crag, Mr. Atkinson dug out a cetacean vertebra ( $6 \frac{1}{3}$ ins. long by $5 \frac{\pi}{4}$ wide) probably belonging to one of the ziphioid whales known as Mesoplodon. This specimen was very generously made over to the Museum of Practical Geology by the discoverer. A walk of about two miles brought the party back to Bentley Station.

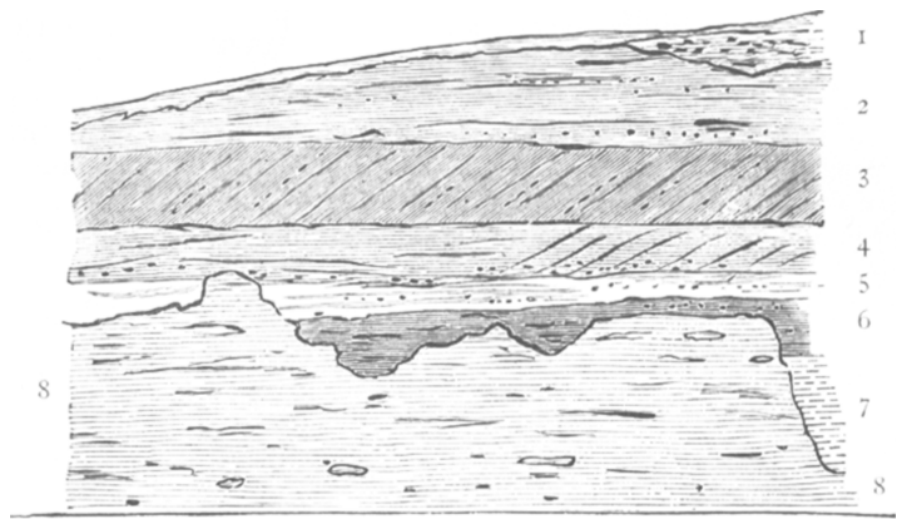

SECTION AT PARK FARM, TATTINGSTONE, NEAR IISWTCH.Sir Goseph Prestwich.

Course Gravel.

Red Clag, i2 feet.

I.

2. ()chreous sands with seams of ironstone, etc.

3. Crag with a few coprolites.

4. Light-coloured (rag.

5. While sand.

v. Brown loam

7. liace of old cliff, depth not shown.

Comalline Crag, 8 leet. S.

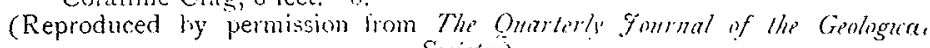
Snictiv)

The district is generally a good collecting ground for Red Crag fossils, and is the farthest known southern exposure of the Coralline Crag.

REFERENCES.

Geological Survey Map, Sheets 4.8, N.W., 48 N.E.

Geological Survey Index Map, Sheet I2, colour-printed. Price 2s. 6d.

I87r. TREstwich, Sin JOSTPH. "Crag Beds of Suffolk and Norfolk." Part ii. Ohart. Fon'm. Geol. So

IS85. WhITAKlis, W.- "The Geology of the Cutntry lound Ipswich, etc." Mtm. Geo. Sint. Price as.

I89o. Rrin, C:-"Pliocene Deposits of Britain." Men. Geol. Surr. Price 5s. Gd.

See "Record of Excursions," p. Is7, st seg., for report of former excursions to Suffillk. 